\title{
Influence of Nitrogen Fertilization on Traits Related to Lodging and Yield in Bread Wheat Genotypes
}

\section{Elashry, Shimaa T.M.; B.R. Bakheit; K.A. Kheiralla and S.F. Elnaksh}

Received on: $29 / 4 / 2020$

Agron. Dept., Fac. of Agric., Assiut Univ., Egypt.

Abstract

The study was carried out during 2017/2018 and 2018/2019 seasons at the Exp. Farm of Assiut University, to Evaluate 20 bread wheat genotypes (Triticum aestivum $\mathrm{L}$ ) for traits related to lodging resistance and yield under different levels of nitrogen fertilization i.e. 50, 75 and $100 \mathrm{~kg} \mathrm{~N} / \mathrm{fed}$.

The results could be summarized as follow:

- There were highly significant differences among the studied genotypes, levels of nitrogen and genotypes $\mathrm{x}$ nitrogen interaction traits related to lodging.

- Plant height was positively and high significantly correlated with the second internode length under all nitrogen levels, while it was negatively highly significantly correlated with second internode diameter with an increase nitrogen levels.

- The mean plant height and length of second internode over all genotypes increased as nitrogen rate increased up to $100 \mathrm{~kg} \mathrm{~N} / \mathrm{fed}$.

- Increasing nitrogen rate up to $75 \mathrm{~kg} / \mathrm{fed}$. led to significant increase in the stem diameter, dry weight/unit and internode length. However, adding more nitrogen fertilizer showed negative effect on the above mentioned traits.

- The lodging percentage increased with the increase of nitrogen rate. The causes of lodging differed from cultivar to another.

- The grain yield significantly increased with the increase of nitrogen rate up to $100 \mathrm{~kg} / \mathrm{fed}$.

- Results showed that the genotype Sakha 93 was the best for lodging percentage.

Keywords: Evaluation, wheat genotypes, Lodging, Nitrogen fertilizer.

\section{Introduction}

Wheat is the world's most important cereal crop that excels all other cereal crops both in area and production. Besides wheat provides nutrition to most of the world population and is well adapted to a wide range of environmental conditions (Vamshikrishna et al., 2013 and Olga et al., 2018). Moreover, wheat is the strategic cereal crop not only in Egypt, but also all over the world. In Egypt, wheat is ranking the first among winter cereal crops (Galal et al., 2016). Wheat grains are the main source of calories and protein in the most developing countries including Egypt. In addition, the wheat straw is the main source of fodder for animal feed to support the rapidly developing animal production (Galal et al., 2016 and Bayisa 2019).

The cultivated area of wheat in Egypt during 2018 season was about 1.32 million hectares with a total grain or straw production of 8.45 million metric ton. While the total consumption reached about 19.6 million metric tons (USDA, 2018). With consumption gap, increasing wheat production in order to reduce the gap be- 
tween production and consumption is a strategic aim.

Efforts of scientists to minimize the gap between local production and consumption are directed towards two ways i.e. expanding the cultivated wheat area and increasing the wheat productivity from the land unit area by selecting high yielding varieties and balanced fertilization (Atia and Ragab, 2013).

Nitrogen $(\mathrm{N})$ fertilizers are the major input required and limiting factor for cereal crop production worldwide. The management of this resource is a significant challenge to most agricultural systems as it can have significant impacts on yield and the environment (Abdullah 2011; and Inwati et al., 2018). The proper amount of fertilizer application is considered a key to the bumper crop production (Tariq et al., 2007). Despite being one of the most abundant elements on earth, $\mathrm{N}$ deficiency is one of the most common problems affecting plant growth worldwide (Abdullah 2011). In addition, since nitrogen is the element which stimulates above-ground growth and produces the rich, green color characteristic of healthy plant and increases the protein percentage it plays a direct effect on growth behavior and yield quality (Yasser and Naheif, 2018). The application of proper amount of nitrogen is the key to obtain higher grain yield of wheat in Egypt. (Mosslem et al 2014 and Atia and Ragab, 2013).

Wheat genotypes could be considered one of the most favorable factors affecting grain yield (Seleem and Abd El-Dayem, 2013) optimal use of production parameters, such as nitro- gen and genotypes may improve grain yield and quality, resulting in higher economic benefits (Bhatta et al., 2017).

Lodging is one of the constraints that limit wheat yields and quality due to the unexpected bending or breaking stems on wheat production worldwide. Moreover, it can increase susceptibility to pests and diseases (Berry et al., 2004; Zhang et al., 2017 and Zenhom 2018) and present extreme problem in harvesting operation (Telkar et al., 2017) Severe lodging destroys plant morphology, and reduces photosynthetic efficiency, grain yield, grain filling, and harvesting efficiency (Berry and Spink, 2012). Beside choosing lodging resistance varieties, husbandry practices also have a significant effect on lodging. Nitrogen management is one of the most common and efficient methods that were used widely in rainfed winter wheat production to reduce lodging risk (Can et al., 2015, Peake et al., 2016 and Zhang et al., 2017). Supply the optimum dose of $N$ helps to reduce lodging losses (Telkar et al., 2017).

The objectives of the current study were evaluation of 20 genotypes of bread wheat under three levels of $\mathrm{N}$ fertilization i.e. 50, 75, 100 $\mathrm{kg} \mathrm{N} / \mathrm{fed}$ for yield and estimate the extent of lodging resistance of each genotype traits, i.e. plant height, second internode length, stem diameter and dry weight/unit

\section{Materials and Methods}

This study was carried out during the two successive growing seasons 2017/2018 and 2018/2019 at the Agronomy Department, Experimental Farm, Faculty Agriculture, Assuit 
University to evaluate twenty wheat genotypes for yield and its components preside lodging resistance related traits under three levels of nitrogen fertilization. The soil type was clay in texture. The physical and chemical analyses of the experimental soil are presented in Table 1.

Table 1. Some physical and chemical properties of the experimental soil.

\begin{tabular}{|l|c|c|}
\hline Properties & $\mathbf{2 0 1 7 / 2 0 1 8}$ & $\mathbf{2 0 1 8 / 2 0 1 9}$ \\
\hline Mechanical analysis: & 27.00 & 27.80 \\
Sand & 23.00 & 22.20 \\
Slit & 50.00 & 50.00 \\
Clay & Clay & Clay \\
Soil type & 7.63 & 7.85 \\
Chemical analysis: & 1.80 & 1.70 \\
pH & 0.09 & 0.08 \\
Organic matter \% & & \\
Total N\% & & \\
\hline
\end{tabular}

Plant material and field experiments.

Twenty bread wheat genotypes (Table 2) were sown on Dec. $5^{\text {th }} 2017$ and Nov $28^{\text {th }}$ 2018. A randomized complete block Design of three replications was used in both levels of nitrogen and seasons.

Experiments plots consisted to 6 rows, $20 \mathrm{~cm}$ apart, and $2.0 \mathrm{~m}$ long (plot $\operatorname{area}=2 \mathrm{~m}^{2}$ ). The harvest was May $3^{\text {rd }} 2018$ and $15^{\text {th }} 2019$. In the first and second growing seasons, respectively. The ordinary cultural practices for growing wheat were adopted as recommended, except the experimental treatments (Nitrogen fertilizer) in both seasons. Three levels of Nitrogen fertilization, i.e., 50, 75 and $100 \mathrm{Kg} /$ fadden in the form of Urea $(46.5 \% \mathrm{~N})$ were applied into three equal doses before first, second and third irrigation. 
Table 2. The pedigree and origin of studied genotypes.

\begin{tabular}{|c|c|c|c|}
\hline Ser NO & Genotypes & Pedigree & Origin \\
\hline 1 & MISR 1 & OASIS/SKAUZ//4*BCN/3/2*PASTOR & Egypt \\
\hline 2 & Sakha 93 & SAKHA 92/TR 810328 & Egypt \\
\hline 3 & Sakha 94 & Opta/Rayon//KAVZ & Egypt \\
\hline 4 & Shandaweel-1 & $\begin{array}{c}\text { SITE/MO/4/NAC/TH.AC//3*PVN/3/MIRLO/ } \\
\text { BUC. }\end{array}$ & Egypt \\
\hline 5 & Sids-1 & $\begin{array}{l}\text { HD2172/PAVON "S"//1158.57/MAYA } 74 \text { "S". } \\
\text { SD46-4SD-2SD-ISD-OSD. }\end{array}$ & Egypt \\
\hline 6 & Sids-13 & ALMAZ.19=KAUZ"S"//TSI/SNB"S" & Egypt \\
\hline 7 & Giza 171 & SAKHA 93/GEMMEIZA 9 S.6-1GZ-4GZ-1GZ-2GZ-0S & Egypt \\
\hline 8 & Gemmiza 9 & ALD “S”/HUAC “S”//CMH 74 A. 630/SX & Egypt \\
\hline 9 & 103 Mohasan & Agronomy Dep., Fac. Agric., Assiut Univ. & Egypt \\
\hline 10 & Entry 13 & $\begin{array}{c}\text { ND643/2*WBLL1/4/WHEAR/KUKUNA/3/C } 80.1 / 3 * \\
\text { BATAVIA//2*WBLL1 }\end{array}$ & $\begin{array}{c}\text { MXI13- } \\
\text { 14\M35ES22SAWHT\21 }\end{array}$ \\
\hline 11 & Entry 16 & MUU/FRNCLN & $\begin{array}{l}\text { MXI13- } \\
\text { 14\M35ES22SAWHTI31 }\end{array}$ \\
\hline 12 & Entry 19 & BAJ \#1/KISKADEE \#1 & $\begin{array}{c}\text { MXI13- } \\
\text { 14\M35ES22SAWHTI37 }\end{array}$ \\
\hline 13 & Entry 20 & CHEWINK \#1/MUTUS & $\begin{array}{c}\text { MXI13- } \\
\text { 14\M35ES22SAWHT\43 }\end{array}$ \\
\hline 14 & Entry 21 & SERI.1B*2/3/KAUZ*2/BOW//KAUZ/4/2*MUNAL & $\begin{array}{c}\text { MXI13- } \\
\text { 14\M35ES22SAWHT\50 }\end{array}$ \\
\hline 15 & Entry 23 & QUAIU \#1/2*SUP152 & $\begin{array}{c}\text { MXI13- } \\
\text { 14IM35ES22SAWHTI54 }\end{array}$ \\
\hline 16 & Entry 24 & MUNAL*2/WESTONIA & $\begin{array}{c}\text { MXI13- } \\
\text { 14\M35ES22SAWHT\68 }\end{array}$ \\
\hline 17 & Entry 25 & MUTUS*2/HARIL \#1 & $\begin{array}{c}\text { MXI13- } \\
\text { 14IM35ES22SAWHT\74 }\end{array}$ \\
\hline 18 & Entry 30 & SWSR22T.B./2*BLOUK \#1//WBLL1*2/KURUKU & $\begin{array}{c}\text { MXI13- } \\
\text { 14\M35ES22SAWHT\94 }\end{array}$ \\
\hline 19 & Entry 42 & $\begin{array}{c}\text { CROSBILL } \\
\text { \#1/DANPHE/7/CNDO/R143//ENTE/MEXI_2/3/AEG ILOPS } \\
\text { SQUARROSA } \\
\text { (TAUS)/4/WEAVER/5/2*KAUZ/6/PRL/2*PASTOR }\end{array}$ & $\begin{array}{l}\text { MXI13- } \\
\text { 14\M35ES22SAWHT } \backslash 122\end{array}$ \\
\hline 20 & Entry 46 & WAXWING*2/TUKURU//2*FRNCLN & $\begin{array}{c}\text { MXI13- } \\
\text { 14\M35ES22SAWHT \153 }\end{array}$ \\
\hline
\end{tabular}

The following traits were recorded for all experiments:

1. Plant height $(\mathbf{P H} \mathbf{~ c m})$ : measured as the distance from the ground surface to the base of the main culm spike for average ten plants from each genotype.

2. Second internode length (SIL, $\mathbf{c m})$ : measured as the distance from the first node to the second internode of the main stem.

3. Stem diameter (SD, mm): measured in as diameter of the second internode.

4. Dry weight per unit length of the second internode (DWSI) was calculates as the dry weight of 
the second internode divided by its length.

5. Field loading: estimated as the type of damage assessed was lodging, where the stems inclined at $45^{\circ}$ from the horizontal. The proportion of the plot area affected by lodging was assessed as the percentage of lodged plants to the total plants, according to Dorofeev and Ponomarev (1970).

6. Grain yield $/ \mathrm{m}^{2}(\mathbf{G Y})$ : it was calculated on plot main in $\mathrm{g} / \mathrm{m}^{2}$.

Statistical analysis:

The separate and combined analyses of variance were done on plot mean basis after testing homogeneity of error according to Gomez and Gomez (1984). After testing the significance of variances, revised LSD were calculated to compare differed genotypes means.

\section{Results and Discussion}

The performance of bread wheat genotypes under nitrogen levels for plant height, yield and traits related to lodging (second internode length, stem diameter and dry weight/unit length) in the present investigation were presented as follows:

A- Analysis of variance of bread wheat genotypes under nitrogen levels for traits related to lodging resistance.

Separate analysis of variance in each seasons revealed highly significant differences among the genotypes as well as three levels of nitrogen for all studied traits i.e. plant height, second internode length, dry weight/unit, stem diameter and grain yield $\mathrm{m}^{2}$ (Table 3 ).

Combined analysis of variance for the studied traits over the two seasons, revealed highly significant differences among the three levels of nitrogen, genotypes and the interaction of nitrogen level $\mathrm{x}$ genotypes (Table 4). 
Doi: 10.21608/ajas.2020.114369

Elashry,et al., 2020

http://ajas.journals.ekb.eg/ 
These results indicate that the studied genotypes responded differently when they were grown at different levels of nitrogen. These results are in agreement with Abdel Nour et al. (2011), Abd El-Raouf et al. (2013), Ati et al. (2016), and Morsy et al. (2018). Hindi et al. (1990) found low significantly of variety $\mathrm{x}$ season $\mathrm{x}$ nitrogen interaction for traits related to lodging resistance traits. Also, several workers reported significantly different genotypic for nitrogen level interaction. Kheiralla $e t$ al. (1993) and Ismail (2001).

\section{B- Performance of the genotypes under nitrogen levels:}

\section{1- Plant height, (cm):}

The mean plant height over all genotypes increased as nitrogen rate increased up to $100 \mathrm{~kg}$ N/fed. Their average were $85.60,85.50$ and 85.55 with $50 \mathrm{~kg} 94.80,96.80$ and 95.80 with $75 \mathrm{~kg}$ and 107.90, 112.80 and $110.35 \mathrm{~cm}$ with $100 \mathrm{~kg} \mathrm{~N} / \mathrm{fed} \mathrm{in}$ 2017/2018 and over both seasons, respectively (Table 5).

In the first season under level of $50 \mathrm{~kg} \mathrm{~N} / \mathrm{fed}$, the average plant height ranged from 83.00 for Sakha 93 to 90.33 for Sakha 94 with an average of $85.60 \mathrm{~cm}$. Under level of $75 \mathrm{~kg}$ $\mathrm{N} /$ fed, the average ranged from 90.00 for Sakha 93 to 102.67 for Sakha 94.82 with an average of $94.80 \mathrm{~cm}$. Also, under level of $100 \mathrm{~kg} \mathrm{~N} / \mathrm{fed}$, the average ranged from 98.33 for Entry
21 to 117.30 for Gemmeiza 9 with an average of $107.90 \mathrm{~cm}$ (Table 5).

In the second season under level of $50 \mathrm{~kg} \mathrm{~N} / \mathrm{fed}$, the average plant height ranged from 82.30 for Entry13 to 89.70 for Sids 1 with an average of $85.50 \mathrm{~cm}$. Under level of $75 \mathrm{~kg}$ $\mathrm{N} / \mathrm{fed}$, the average of plant height ranged from 88.30 for Entry13 to 104.30 for Entry 25 with an average of $96.80 \mathrm{~cm}$. Also, under level of 100 $\mathrm{kg} \mathrm{N} /$ fed ranged from 100.00 for Entry 13 to 124.67 for Entry 25 with an average of 112.80 (Table 5).

The same trend over could be found the two seasons. Saad (2007) mentioned that the increase in plant height when the nitrogen was applied at 80 and $100 \mathrm{~kg} \mathrm{~N} / \mathrm{fed}$, were $1.57 \%$ and $3.47 \%$, respectively. The same trend was found by Rekaby et al. (2016), El-Hag and Shahein (2017), El-Temsah (2017), Solomon and Anjulo (2017), Yadav and Dhanai (2017) and Farooq et al. (2018). Differences for the obtained result may be attributed to the genetic variations among the studied genotypes of wheat. The increase of nitrogen dose may be increase the photosynthetic prosses in plants, thereby increase the plant height, due to cell division as well as cell elongation. These results are in agreement with those reported by Hassanein et al. (2013), Zaky et al. (2015), Kandil et al. (2016), ElHag (2017) and Warda et al. (2020). 
Doi: 10.21608/ajas.2020.114369

Elashry,et al., 2020

http://ajas.journals.ekb.eg/ 
2. Second internode length $(\mathrm{cm})$ :

In general mean of second internode length for all genotypes was high due to the high levels of nitrogen (Table 6).

In the first season under level of $50 \mathrm{Kg} \mathrm{N} / \mathrm{fed}$, the average of second internode length ranged from 4.16 for Gemmeiza 9 to 5.82 for Entry 16 with an average of $5.03 \mathrm{~cm}$. Under level of $75 \mathrm{~kg} \mathrm{~N} / \mathrm{fed}$, the average ranged from 5.72 for Entry 21 to 7.78 for Sids 1 with an average of 6.73 $\mathrm{cm}$. Also, under level of $100 \mathrm{~kg}$ $\mathrm{N} /$ fed, the average ranged from 6.77 for Entry 21 to 90.00 for Sids 1 with an average of $7.99 \mathrm{~cm}$.

In the second season under level of $50 \mathrm{~kg} \mathrm{~N} / \mathrm{fed}$, the average second internode length ranged from 4.23 for Entry 42 to 5.60 for Giza 171 with an average of $4.79 \mathrm{~cm}$. Under level of 75 $\mathrm{kg} \mathrm{N} / \mathrm{fed}$. The average of second internode length ranged from 6.80 for Shandaweel 1 to 8.3 for Entry 16 with an average of $7.45 \mathrm{~cm}$. Also, under level of $100 \mathrm{~kg} \mathrm{~N} / \mathrm{fed}$, ranged from 7.80 for Entry 20 to 9.00 for Entry 16 with an average of $8.39 \mathrm{~cm}$
(Table 6). The same trend proposed over the two seasons. The mean second internode length over all genotypes increased as nitrogen rate increased up to $100 \mathrm{~kg} \mathrm{~N} / \mathrm{fed}$. The same results were found by Kheiralla et al. (1993), Ismail (2011) and Zhang et al (2017) who found an increase of 10$25 \%$ in the length of the three lowest internodes due to high nitrogen levels in wheat. Pinthus (1973) reviewed that the increase of internode length may be due to cell division as well as cell elongation. Ahmed et al. (2000) and Zhang et al. (2017) found that plant height was highly significantly correlated with the second internode length. The promotion of the weakening of the basal internode due to increased nitrogen supply have been found to enhance lodging (Pinthus, 1973 and Zhang et al. 2017). Kheiralla et al. (1993), Ismail (2011) and Zhang et al. (2017). Tripathi (2003) and Zhang et al. (2017) found that length of basal internodes negatively associated with lodging resistance. 
Doi: 10.21608/ajas.2020.114369

Elashry,et al., 2020

http://ajas.journals.ekb.eg/ 


\section{Stem diameter (mm):}

In general, stem diameter showed significant increase with increasing $\mathrm{N}$ rate up to $75 \mathrm{~kg} / \mathrm{fed}$. However, adding more nitrogen fertilizer had negative effect on this trait (Table 7).

In 2017/2018 Season under level of $50 \mathrm{~kg} \mathrm{~N} / \mathrm{fed}$, the average stem diameter ranged from 2.70 for Entry 16 to 3.10 for Entry 46 with an average of $2.90 \mathrm{~mm}$. Under level of 75 $\mathrm{Kg} \mathrm{N} / \mathrm{fed}$, the average ranged from 3.30 for Entry 19 to 4.00 for Entry 24 with an average of $3.80 \mathrm{~mm}$. Also, under level of $100 \mathrm{Kg} \mathrm{N} / \mathrm{fed}$, the average ranged from 3.10 for Entry 19 to 3.80 for Entry 46 with an average of $3.40 \mathrm{~mm}$ (Table 7).

In 2018/2019 season under level of $50 \mathrm{Kg} \mathrm{N} / \mathrm{fed}$, the average stem diameter ranged from 2.30 from Entry 30 to 3.00 for Shandaweel 1 with an average of $2.70 \mathrm{~mm}$. Under level of $75 \mathrm{Kg} \mathrm{N} / \mathrm{fed}$, the average of stem diameter ranged from 3.40 for Sakha 94 to 4.10 for Entry 24 with an average of $3.90 \mathrm{~mm}$. Also, under level of 100 $\mathrm{kg} \mathrm{N} /$ fed, ranged from 3.00 for Sakha 94 to 3.70 for Sakha 93 with an average of $3.30 \mathrm{~mm}$ (Table7). The same trend extended over the two seasons. The same trend was found by Pinthus (1973), Kheiralla et al. (1993), Ismail (2011), and Zhang et al (2017). The high rate of $100 \mathrm{~kg} \mathrm{~N}$ led to an increase of plant height but not stem diameter, this is one well known effect of nitrogen. Ahmed et al. (2000) found that plant height was not significantly correlated with stem diameter. Awad (1987) reported that a positive correlation for lodging resistance with stem diameter. Ismail (2001) indicated that The level of 100 $\mathrm{kg} \mathrm{N} / \mathrm{fed}$. treatment produced the plant height/stem diameter ratio (28.81) and the lowest diameter/length ratio (0.406) for the second internode. These two ratios imply that the high $\mathrm{N}$ rate results in stems that are thin, tall, with less dry matter that is reflected on a high percentage of lodging (15.00\%). This is supported by the findings of Kheiralla et al (1993), Ahmed et al. (2000) and Zhang et al (2017). Awad (1987) showed lodging resistance was positively correlated with stem diameter of second of internode.

Pinera et al 2016 reported that grain yield was associated positively with stem diameter and positive associations between stem dry weights per unit length with stem diameter. Previous studies showed that significant correlations between the lodging score and several morphological traits were found for stem diameter (Zuber et al., 1999 and Kong et al., 2013). 
Doi: 10.21608/ajas.2020.114369

Elashry,et al., 2020

http://ajas.journals.ekb.eg/ 


\section{Dry weight per unit length of the second internode $(\mathrm{g})$ :}

In 2017/2018 season under level of $50 \mathrm{~kg} \mathrm{~N} / \mathrm{fed}$, the average dry weight per unit length of the second internode ranged from 1.80 for Entry 13 to $2.80 \mathrm{~g}$ for Entry 16 with an average of $2.40 \mathrm{~g}$. Under level of $75 \mathrm{~kg}$ $\mathrm{N} / \mathrm{fed}$, the average ranged from 2.57 for Entry 13 to 3.90 for Sids 1 with an average of $3.32 \mathrm{~g}$. Also, under level of $100 \mathrm{~kg} \mathrm{~N} / \mathrm{fed}$, the average ranged from 2.21 for Entry 13 to 3.60 for Sids 1 with an average of $2.87 \mathrm{~g}$ (Table 8).

In 2018/2019 season under level of $50 \mathrm{~kg} \mathrm{~N} / \mathrm{fed}$, the average dry weight per unit length of the second internode ranged from 1.67 from Shandaweel 1 to 3.00 for Giza 171 with an average of $2.42 \mathrm{~g}$. Under level of $75 \mathrm{~kg} / \mathrm{fed}$, the average of second internode length ranged from 2.57 for Entry 13 to 3.90 for Sids 1 with an average of $3.35 \mathrm{~g}$. Also under level of $100 \mathrm{~kg} \mathrm{~N} / \mathrm{fed}$, ranged from 2.21 for Entry 13 to 3.60 for Sids 1 with an average of 2.91 (Table 8 ). The same trend could be found over the two seasons. Dry weight per unit length of the second internode showed significant increase with increasing $\mathrm{N}$ rate up to $75 \mathrm{~kg} / \mathrm{fed}$. However, adding more nitrogen fertilizer had negative effect on the above mentioned trait. The same trend was found by Pinthus (1973), Kheiralla et al. (1993), Ismail (2011), and Zhang et al. (2017). Ahmed et al. (2000) found that plant height was not significantly correlated with dry weight per unit length of the second internode. Tripathi 2003 and Zhang et al. (2017) found that dry weight per of basal internodes were positively associated with lodging resistance. Lodging resistance in wheat was found to be was positively correlated with the dry weight per unit length of the second internode (Awad, 1987, Kheiralla et al. 1993, Ismail (2011). Kheiralla et al. (1993) and Zhang et al (2017) reported that the slight decreases in grain yield at high nitrogen levels were in coincidence with the decrease in dry weight per unit length of the second internode. Tripathi (2003) found that dry weight per unit length was positive correlated with grain yield. Also, positive association was recorded between stem dry weight per unit length and stem diameter. 
Doi: 10.21608/ajas.2020.114369

Elashry,et al., 2020

http://ajas.journals.ekb.eg/ 


\section{5- Percentage of lodging:}

In $2017 / 2018$ season, the percentage of lodging under fertilizer of $50 \mathrm{~kg} \mathrm{~N} /$ fed. ranged from 0 (no lodging) for fourteen genotypes to $1.33 \%$ for genotype 25 with an average of $0.28 \%$. Under fertilizer of $75 \mathrm{~kg}$ $\mathrm{N} / \mathrm{fed}$, it ranged from $0 \%$ for eight genotypes to 7 for Entry 13 with an average of $2.47 \%$. As well as fertilizer with $100 \mathrm{~kg} \mathrm{~N} / \mathrm{fed}$ revealed a percentage of lodging ranged from 4.0 for Entry 21 to $13.33 \%$ for two Entries (24 \& 46) and Giza 171 with an average of $9.23 \%$ (Table 9).

In 2018/2019 season the percentage of lodging under fertilizer of $50 \mathrm{~kg} \mathrm{~N} /$ fed ranged from 0 for seventeen genotypes to 1.33 for Entry 23 with an average of $0.171 \%$. Also under fertilizer of $75 \mathrm{~kg} \mathrm{~N} / \mathrm{fed}$, it ranged from 0.0 for eight genotypes to 7.0 for Entry 21 with an average of $2.23 \%$. But, under fertilizer with 100 $\mathrm{kg} \mathrm{N} / \mathrm{fed}$, the percentage of lodging ranged from 3.67 for Entry 13 to 15.33 for Giza 171 with an average of $9.40 \%$ (Table 9).

Percentage of lodging over two seasons was the same trend in each season which increased with increase the level of nitrogen from 50, 75 to
$100 \mathrm{~kg} \mathrm{~N} /$ fed and recorded 0.23, 2.35 and $9.32 \%$, respectively.

The high lodging percentage with increasing the level of nitrogen fertilizer until $100 \mathrm{~kg} \mathrm{~N} / \mathrm{fed}$ due to the increase of plant height, second internode length, low stem diameter and dry weight/unit.

These results are in line with those reported by Kheiralla et al. (1993) who reported that, the high lodging percentage was attributed to the low dry weight/unit and increase the length of the second internode. Also, Kheiralla (1994) stated that lodging percentage increased with the increase of nitrogen dose. As well as Berry et al. (2000) in England, suggested the controlling nitrogen fertilization under a certain limit could improve lodging resistance. Peng et al. (2014) in China, showed that lodging resistance was significantly correlated with some morphological characteristics particular plant height.

Also, Xiaoguang et al. (2018) and Khan et al. (2019) in China, found that increasing nitrogen fertilization rates are a prerequisite for high yields, but simultaneously increase lodging risk. 
Doi: 10.21608/ajas.2020.114369

Elashry,et al., 2020

http://ajas.journals.ekb.eg/ 


\section{Grain yield $/ \mathrm{m}^{2}$ :}

In the first season under level of $50 \mathrm{~kg} \mathrm{~N} / \mathrm{fed}$, the grain yield ranged from 437.60 for Shandaweel 1 to 560.60 for Sids 1 with an average of $489.10 \mathrm{~g}$. Under level of $75 \mathrm{~kg} \mathrm{~N} / \mathrm{fed}$, the average ranged from 653.30 for Entry 13 to 826.00 for 103 Mohsan with an average of $732.90 \mathrm{~g}$. Also, under level of $100 \mathrm{~kg} \mathrm{~N} / \mathrm{fed}$, the average ranged from 746.40 for Entry 20 to 957.50 for Entry 16 with an average of $855.90 \mathrm{~g}$ (Table 10).

In the second season under level of $50 \mathrm{~kg} \mathrm{~N} / \mathrm{fed}$, the average grain yield ranged from 417.70 for Sids 1 to 559.70 for Entry 23 with an average of $465.11 \mathrm{~g}$. Under level of $75 \mathrm{~kg}$ $\mathrm{N} / \mathrm{fed}$, the average ranged from 663.00 for Entry 20 to 839.30 for Giza 171 with an average of $755.10 \mathrm{~g}$. Also, under level of $100 \mathrm{~kg} \mathrm{~N} / \mathrm{fed}$, ranged from 690.80 for Entry 20 to 861.70 for Entry 19 with an average of $793.70 \mathrm{~g}$ (Table 10). The same trend recorded over the two seasons (Table 10). The combined average of grain yield $/ \mathrm{m}^{2}$ under fertilizer of 50 $\mathrm{kg} \mathrm{N} / \mathrm{fed}$, ranged from $451.00 \mathrm{~m}^{2}$ for Entry 25 to $546.70 \mathrm{~m}^{2}$ for Entry 23 with an average of $477.10 \mathrm{~g} \mathrm{~m}^{2}$. As well as under level of $75 \mathrm{~kg} \mathrm{~N} / \mathrm{fed}$, the grain yield $/ \mathrm{m}^{2}$ ranged from 684.80 for Entry 20 and Sakha 93 to $818.20 \mathrm{~m}^{2}$ for Entry 19 with an average of $744.00 \mathrm{~g} \mathrm{~m}^{2}$. Also, under level of $100 \mathrm{~kg} \mathrm{~N} / \mathrm{fed}$, ranged from 718.60 $\mathrm{m}^{2}$ for Entry 20 to $884.80 \mathrm{~m}^{2}$ for Giza
171 with an average of $824.80 \mathrm{~g} \mathrm{~m}^{2}$ (Table 10). The mean grain yield over all genotypes increased as nitrogen rate increased up to $100 \mathrm{~kg} \mathrm{~N} / \mathrm{fed}$. The results showed highly significant differences among wheat genotypes for grain yield in both seasons. The increase in yield of the genotypes with increasing $\mathrm{N}$ rates up to $100 \mathrm{~kg}$ $\mathrm{N} / \mathrm{fed}$, adequate levels might be due to the role of $\mathrm{N}$ in increasing the leaf area and promote photosynthesis efficiency which promote dry matter production and increase yield. In line with this, improvements in wheat yield and its components under the acceptable increasing $\mathrm{N}$ rates were reported by Rekaby et al. (2016), Zen El-Dein and Seif El-Nasr (2016), ElTemsah (2017) and Solomon and Anjulo (2017).

Yasser and Naheif (2018) noted that the variation of yield and its attributes in response to increasing $\mathrm{N}$ fertilization levels in wheat varieties, to the genetic constitution ability of the genotypes to benefit from the amount of $\mathrm{N}$ applied. These results are in agreement with those mentioned by Atia et al. (2016), Jarecki et al. (2017), Solomon and Anjulo (2017) and Morsy et al. (2018). Moreover, some genotypes gave highly significantly grain yield $/ \mathrm{m}^{2}$. These genotypes could be used to improve grain yield $/ \mathrm{m}^{2}$. 
Doi: 10.21608/ajas.2020.114369

Elashry,et al., 2020

http://ajas.journals.ekb.eg/ 


\section{References}

Abd El-Raouf, R.E., S. F. El Habbasha, M.H. Taha and K.M. Refaie (2013). Effect of Irrigation Water Requirements and Fertigation Levels on Growth, Yield and Water Use Efficiency in Wheat. MiddleEast J. of Sci. Res., 16 (4): 441450.

Abdel Nour, Nadya and Hayam, S.A. Fateh (2011). Influence of sowing date and nitrogen fertilization on yield and its components in some bread wheat genotypes. Egypt. J. Agric. Res., 89 (4).

Ahmed, T.A., H. Tsujimoto and T. Sasakuma (2000). OTLS associated with plant height and related characters in hexaploid wheat. Breeding Science 50: 267-273.

Ati, A.S., A. Hassan and M. Mohammed (2016). Effect of water stress and NPK fertilization on growth, yield of wheat and water use efficiency. J. of Agric. and Vetern. Sci. 9(12): 21-26.

Atia, R. H. and Kh. E. Ragab (2013). Response of some wheat varieties to nitrogen fertilization. J. Soil Sci. and Agric. Eng., Mansoura Univ., Vol. 4 (3): 309 - 319, 2013.

Awad, H.O. (1987). Studies on some characters related to lodging resistance in wheat. M.Sc. Thesis, Fac. of Agric. Zagazig Univ.

Abdullah, B.F. (2011). Evaluation of Nitrogen Use Efficiency (NUE) in Wheat. M.sc.Thesis.

Bayisa, T., E. Habte and M. Amanuel (2019). Evaluation of Bread Wheat (Triticum aestivum L.) Genotypes for Yield Potential and Related Traits Under High Temperature Stress Condition at Middle Awash, Ethiopia. Adv Crop Sci Tech, 7: 1.

Berry, P.M. and J. Spink (2012). Predicting yield losses caused by lodging in wheat. Field Crop. Res. 137: 1926.
Berry, P.M., J.M. Griffin, R. SylvesterBradley, R.K. Scott, J.H. Spink and C.J. Baker (2000). Controlling plant form through husbandry to minimise lodging in wheat. Field Crops Research. 67(1): 59-81.

Berry, P.M., M. Sterling, J.H. Spink, C.J. Baker, R. Sylvester-Bradley, S. Mooney, A. Tams and A.R. Ennos (2004). Understanding and reducing lodging in cereals. Adv Agron., 84:215-269.

Can, W., W.R. Ren, H.Y. Xiao, H. Dan, Y. Hao, Y. Li and Z. Lin Yi (2015). Effects of Nitrogen Fertilizer and Planting Density on the Lignin Synthesis in the Culm in Relation to Lodging Resistance of Buckwheat .Plant Prod. Sci. 18(2): 218-227.

Inwati, D.K., J. Yadav, J.S. Yadav, Giriraj and A. Pandey (2018). Effect of Different Levels, Sources and Methods of Application of Nitrogen on Growth and Yield of Wheat (Triticum aestivum L.). Int. J. Curr. Microbiol. App. Sci. 7(2): 23982407.

Dorofeev, V.F. and V.E. Ponomarev. (1970). Problem of wheat lodging and its overcome. Reference Abstracts by Maximos \& Belkov, MCX. USSR, Mosco 1970 (in Russion).

EL Hag, D.A.A and A.M.E.A. Shahein (2017). Effect of Different Nitrogen Rates on Productivity and Quality Traits of Wheat Cultivars. Egypt. J. Agro. 39 (3): 321-335.

El-Hag, D.A.A. (2017). Effect of Irrigations Number on Yield and Yield Components of Some Bread Wheat Cultivars in North Nile Delta of Egypt. Egypt. J. Agron., 39(2): 137- 148.

El-Temsah, M.E. (2017). Response of wheat yield, its components and technological characteristics to different nitrogen rates and planting 
methods. Egypt. J. Agron., 39 (3): 421-429.

Farooq, M., I. Khan, S. Ahmed, N. Ilyas, A. Saboor, M. Bakhtiar, S. Khan, I. Khan, N. Ilyas and A.Y. Khan (2018). Agronomical efficiency of two wheat (Triticum aestivum L.) varieties against different level of nitrogen fertilizer in subtropical region of Pakistan. Int. J. Environ. Agric. Res., 4 (4): 28-36.

Galal, A.H.; E.A. Ali and H.E. Abdelkader (2016). Response of Two Durum Wheat Cultivars to Irrigation Levels and Nitrogen Fertilizer Splitting. Assiut J. Agric. Sci., 47 (6-2):325-343.

Gomez, K.A. and A.A. Gomez (1984). Statistical Procedures for Agricultural Research. $2^{\text {nd }}$ Edn., John Wily and Sons, New York, pp: 68.

Hassanein, M.S., A.G. Ahmed, N.M. Zaki, H.I. El-Alia and M.M. Tawfik (2013). Response of Two Wheat Cultivars Grown in Newly Cultivated Lands to Iron and Slow Release N Fertilizers. Aust. J. Basic \& Appl. Sci., 7(1): 498-505.

Hindi, L.H.A.; R.A. Mitkees; A.H. ElAttar and M.K. Moshref (1990)/ Effect of genotype, environmental and their interaction on bread wheat, Proc. $4^{\text {th }}$ Conf. Agron. Cairo, 15-16 Sept. Vol. 1: 13-27.

Ismail, A.A. (2011). Study of some characters related to lodging resistance and yield under different nitrogen levels in bread wheat. Assiut Journal of Agricultural Science, Vol 32, No. 2.

Jarecki, W., J. Buczek and D. B. Jamro (2017). Response of spring wheat to different soil and foliar fertilization. J. of Central Europ. Agric. 18(2), p.460-476.

Kandil, A.A., A.E.M. Sherief, S.E. Seadh and D.S.K. Altai (2016). Role of humic acid and amino acids in limiting loss of nitrogen fer- tilizer and increasing productivity of some wheat cultivars grown under newly reclaimed sandy soil. Int. J. Adv. Res. Biol. Sci., 3 (4): 123-136.

Khan, A., H.H. Liu, A. Ahmad, L. Xiang, W. Ali, M. Kamran, S. Ahmad and J.C. Li (2019). Impact of Nitrogen Regimes and Planting Densities on Stem Physiology, Lignin Biosynthesis and Grain Yield in Relation to Lodging Resistance in Winter Wheat (Triticum aestivum L.) Cereal research communications 3 566-579.

Kheiralla, K.A. (1994). Inheritance of earliness and its relation with yield and drought tolerance in spring wheat. Assiut J. Agric. Sci., 25: 129-139.

Kheiralla, K.A., E.E. Mehdi and R.A. Dawood (1993). Evaluation of some wheat cultivars for traits related to lodging resistance under different levels of nitrogen. Presses de Sciences Po. 53: 135-147.

Kong, E.Y., D.C. Liu, X.L. Guo, W.L. Yang, J.Z. Sun and X. Li (2013). Anatomical and chemical characteristics associatedwith lodging resistance in wheat. The Crop Journal. 1(1): $43 \pm 49$.

Bhatta, M., K.M. Eskridge, D.J. Rose, D.K. Santra, P.S. Baenziger and T. Regassa (2017). Seeding Rate, Genotype, and Topdressed Nitrogen Effects on Yield and Agronomic Characteristics of Winter Wheat. Crop Sci. 57:951-963.

Morsy, A.S.M., A. Awadalla1 and M.M. Sherif (2018). Effect of Irrigation, Foliar Spray with Nano-fertilizer (Lithovit) and N-levels on Productivity and Quality of Durum Wheat under Toshka Conditions. Assiut J. Agric. Sci., 49 (3): 1-26.

Mosslem, S.H.A., F.M.F. AbdelMotagally, G.R. El-Nagar and R.A. Dawood (2014). Response of 
Wheat Productivity to Different Rates of Compost and Nitrogen Fertilizer Under New Valley Conditions. Assiut J. Agric. Sci., 45 (3): 1-12.

Olga, S. Walsh, Sanaz Shafian and Robin J. Christiaens (2018). Nitrogen Fertilizer Management in Dry land Wheat Cropping Systems. Plants 7: 9.

Peake, A.S., K.L. Bell, P.S. Carberry, N. Poole and S.R. Raine (2016). Vegetative nitrogen stress decreases lodging risk and increases yield of irrigated spring wheat in the subtropics. Crop and Pasture Science, 67(9):907-921.

Peng, D.L., X.G. Chen, Y.P. Yin, K.L. Lu, W.B. Yang and Y.H. Tang (2014). Lodging Resistance of winter wheat (Triticum aestivum L): Lignin accumulation and its related enzymes activities due to the application of paclobutrazol or gibberellin acid. Field Crops Research. 157(2): 1-7.

Pinera, F.J.C., P.M. Berry, M.J. Foulkes, G. Molero and M.P. Reynolds (2016). Avoiding lodging in irrigated spring wheat. II. Genetic variation of stem and root structural properties. Field Crops Research, 196: 64-74.

Pinthus, M.J. (1973). Lodging in wheat, barley and oats. The phenomenon, its causes and preventive measures. Adv. in Agron. 25: 209263.

Rekaby, S.A., M.A. Eissa, S.A. Hegab and H.M. Ragheb (2016). Effect of nitrogen fertilization rates on wheat grown under drip irrigation system. Assiut J. Agric. Sci., 47 (3): 104-119.

Saad, M. (2007). Response of wheat to nitrogen fertilizer and water stress at different growth stages. M.Sc. Thesis, Agron. Dept., Fac. Agric., Assiut Univ.
Seleem, S.A. and S.M. Abd El-Dayem (2013). Response of some wheat cultivars to nitrogen fertilizer levels. J. Plant Production, Mansoura Univ., 4 (5): 721-731.

Solomon, W. and A. Anjulo (2017). Response of Bread Wheat Varieties to Different Levels of Nitrogen at Doyogena, Southern Ethiopia. Int. J. Sci. and Res. Public., 7(2): 452459.

Tariq, J.M.T., M. Arif, H. Akbar and S. Ali. (2007). Response of wheat to source, type and time of nitrogen application. Sarhad J. Agric. 23 (4): 871-879.

Telkar, S.G., S.P.S. Solanki1, S. Chouhan1, R. Kumar and S.B. Nikas (2017). Crop Lodging on Cereals: Causes, Effect and Control. Biomolecule Reports- An International Newsletter BR/11/17/12.

Tripathi, S.C., K.D. Sayre, J.N. Kaul and R.S. Narang (2003). Growth and morphology of spring wheat (Triticum aestivum L.) culms and their association with lodging: effects of USDA genotypes, $\mathrm{N}$ levels and ethephon.

Htpp://apps.fsa.usda.gov/psolonli e/circulars/Production.

Vamshikrishna, N., N.R. Potdukhe, S. Bharad, S. Deshmukh and S.M. Shinde (2013). Genetic variability, correlation and path analysis in wheat. J. Wheat Res. 5 (2): 48-51.

Warda, H.S, R.A. Dawood, K.A. Abd El-Rahman, M.A. El-Morshidy and A.H. Galal (2020). Impact of humic acid and nitrogen fertilization on productivity of some bread wheat cultivars (In Press).

Xiaoguang, C., J. Wang, Z. Wang, W. Li, C. Wang, S. Yan, H. Li, A. Zhang, Z. Tang and M. Wei (2018). Optimized nitrogen fertilizer application mode increased culms lignin accumulation and lodging resistance in culms of win- 
ter wheat. field crops research 228 : 31-38.

Yadav, M.S. and C. Dhanai (2017). Effect of different doses of nitrogen and seed rate on various characters and seed yield of wheat (Triticum aestivum L.). J. Pharmacogn. Phytochem., 6 (2): 1-5.

Yasser, A.M.H. and E. Naheif (2018). Behavior of some Bread Wheat Genotypes under Different Planting Dates and Nitrogen Fertilizer Levels in Sohag Governorate. Assiut J. Agric. Sci., 49 (2): 1-14.

Zaki, N.M., A.G. Ahmed, M.S. Hassanein and M.E. Gobarah (2015). Response of two wheat cultivars to foliar fertilizer in newly cultivated land. Gobarah. Middle East J. Agric. Res., 4 (2): 283-290.

Zen El-Dein, A.A.M. and F.M. Seif ElNasr (2016). Effect of residual and straw for three preceding crops on growth, yield and yield components of wheat under different nitrogen fertilizer levels. J. Agric.
Res. Kafr El-Sheikh Univ., 42 (2): 160-172.

Zenhom, M.F.T, G.Y. Hammam and S.A.S. Mehasen (2018). Wheat Lodging and Yield in Response to Cultivars and Foliar Application of Paclobutrazol. $4^{\text {th }}$ International Conference on Biotechnology Applications in Agriculture (ICBAA), Benha University, Moshtohor and Hurghada, 4-7 April 2018, Egypt.

Zhang, M., H. Wang, Y. Yi, J. Ding, M. Zhu and C. Li (2017). Effect of nitrogen levels and nitrogen ratios on lodging resistance and yield potential of winter wheat (Triticum aestivum L.). PLoS ONE 12(11): e0187543.

Zuber, U., H. Winzeler, M.M. Messmer, M. Keller, B. Kellerand J.E. Schmid (1999). Morphological traits associated with lodging resistance of spring wheat (Triticum aestivum L.). Journal of Agronomy \& Crop Science. 182(1): 17-24. 
Website: www.aun.edu.eg/faculty_agriculture/journals_issues_form.php E-mail:ajas@aun.edu.eg

تأثير التسميد النيتروجيني علي الصفات ذات العلاقة بالرقاد والمحصول في تراكيب وراثية من

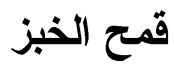

شيماء ثروت محمود العشري، باهي راغب بخيت، كمال خير الله وصلاح فتوح أبو الوفا قسم المحاصبل - كلية الزر اعة - جامعة أسيوط - أسيوط

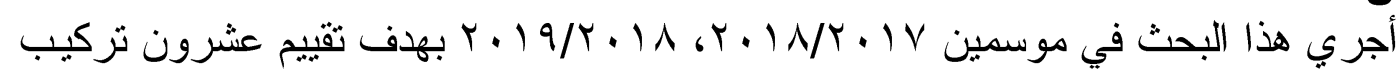

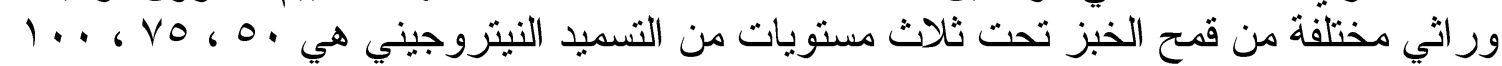

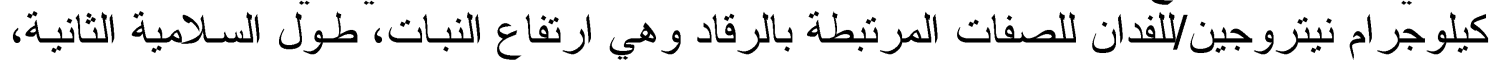

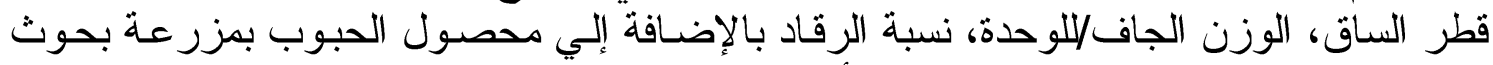

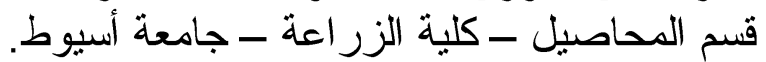

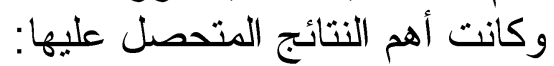

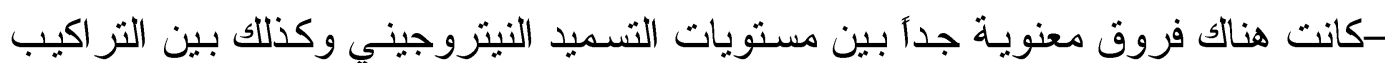

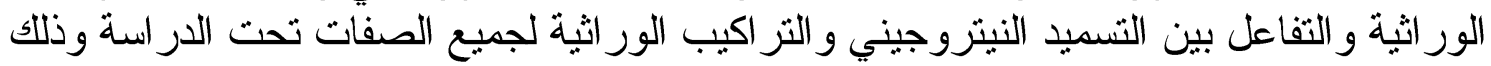
في كلا الموسمين و التحليل المشنرك بين الفين الموسمين.

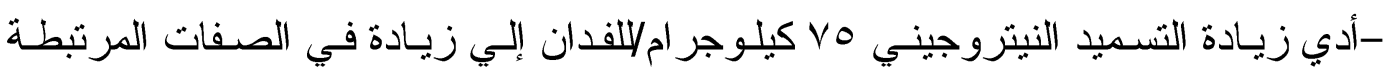

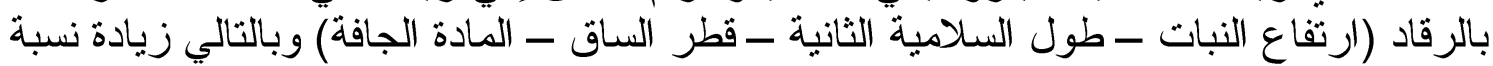

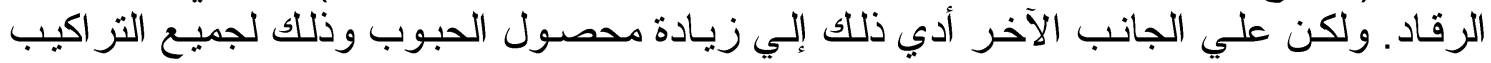
الور اثية في كلا الموسمين.

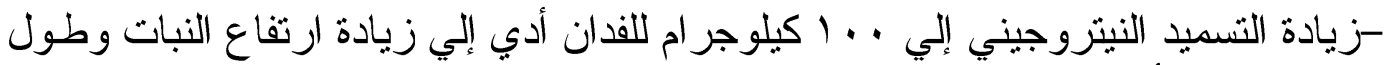

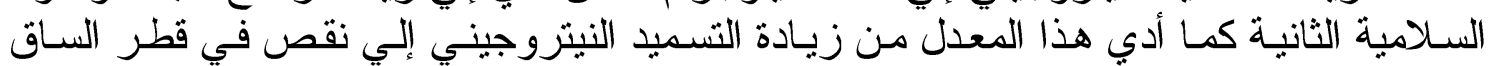
و المادة الجافة/للاوحدة. 